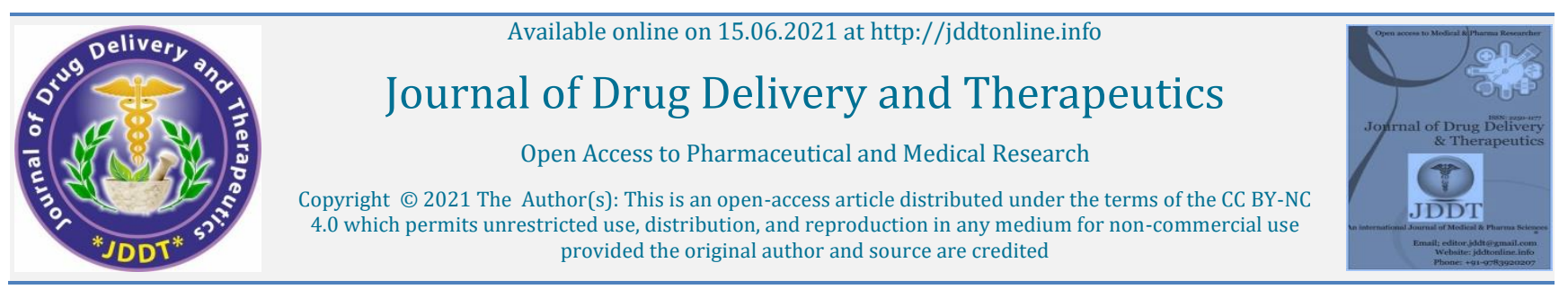

Available online on 15.06.2021 at http://jddtonline.info

Open Access Full Text Article

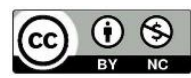

Review Article

\title{
Sharbat- E- Unnab: A Review on Potent Unani Formulation
}

\author{
Anju $^{1 *}$, Ghazala Javed ${ }^{2}$ \\ ${ }^{1}$ Research Associate, Central Council for Research in Unani Medicine, Ministry of AYUSH, Govt. of India, New Delhi, India \\ ${ }^{2}$ Research Officer, Scientist-IV, Central Council for Research in Unani Medicine, Ministry of AYUSH, Govt. of India, New Delhi, India
}

\begin{tabular}{ll}
\hline Article Info: & \\
\hline 0 & Article History: \\
& Received 19 April 2021 \\
& Accew Completed 27 May 2021 \\
& Available online 2021 June 2021
\end{tabular}

Cite this article as:

Anju, Javed G, Sharbat- E- Unnab: A Review on Potent Unani Formulation, Journal of Drug Delivery and Therapeutics. 2021; 11(3-S):142-144

DOI: http://dx.doi.org/10.22270/jddt.v11i3-S.4836

\section{*Address for Correspondence:}

Dr. Anju, Research Associate, Central Council for Research in Unani Medicine, Ministry of AYUSH, Govt. of India, New Delhi, India

\author{
Abstract
}

Unani System of Medicine is also known as Greco-Arabic medicine, and developed into an elaborate scientific medical system by Arab and Persian physicians, such as Rhazes (850925AD), Avicenna (980-1037AD), Al-Zahrawi and Ibn Nafis. It is practiced in India since eighth century AD and is a recognized Indian traditional system of medicine with good infrastructure for education; research and manufacturing unitswhich are well regulated by the Government. In Unani medicine there are well developed pharmacopeia and pharmaceutical processings for single \& compound formulations for the treatment of several local and systemic ailments. The most important formulation among various Unani formulations is Sharbat-e-Unnab, a Unani pharmaceutical preparation acting as Dafa-e-Sual (antitussive), Khashunat-e-Halaq (sore throat), Musaffi-e-Khoon (blood purifier), Musakkine-Hiddat-e-Khoon (suppressive blood heat) etc. Unnab (Ziziphus jujuba Mill. / Jujube) fruit is the main ingredient of the formulation. Unnab is also an ingredient of Unani Joshanda which has been recommended for relief in upper respiratory tract symptoms in mild cases of COVID-19. Few scientific studies related to Sharbat Unnab have been conducted in problems like Acne vulgaris and Primary Hypertension. Apart from this Unnab, the main ingredient has also been studied for its antioxidant and anti-cancerous activities. This formulation is being used by Unani physicians since time immemorial. Therefore, this paper will describe the brief review of the formulation along with its ingredient.

Keywords: Sharbat-e-Unnab, Unani medicine, Sharbat, Unnab, Ziziphus Jujuba Mill.

\section{INTRODUCTION}

Unani System of Medicine is also well-known as Greco-Arabic medicine, and developed into an elaborate scientific medical system by Arab and Persian physicians, such as Rhazes (850925AD), Avicenna (980-1037AD), Al-Zahrawi and Ibn Nafis. It was acquainted in India since $18^{\text {th }}$ century AD and become a native soon. Indian Unani physicians such as Akbar Arzani (d.1721 AD), Abu Bakr Kashani, Badruddin Dimashqi (Famous physician of Ala'uddin Khilji's reign) (1190-1248 AD), Bahwa ibn Khwas (d.1519 AD), 'Ali Gilani (1554-1609 AD), Hashim 'Alvi Khan (1669-1749 AD), Ajmal Khan (1868-1927 AD) and Hakim Muhammad Kabiruddin (1894-1976 AD) were valuable contributors for popularization of Unani medicine. The scholars and physicians of Unani system of Medicine settled in India carried out clinical trials and experiments making important additions to the scope of Medicine. Today, India has a strong infrastructure for education, research as well as manufacturing units in Unani medicine.

The system is focused on the Hippocratic theory of Akhlat-eArba (four humours-Dam (Blood), Balgham (Phlegm), Safra (Yellow Bile), and Sauda (Black bile)and Arkan-e-Arba (four elements- Arz (Earth), Hawa (Air), Ma (water) and Nar (fire).In Unani medicine there are well developed pharmacopeia and pharmaceutical processings for single \& compound formulations. Various compound formulations such as Majun (semi-solid preparation), Tiryaq, Khamira, Lauq (linctus), Huboob (pills), Aqras (tablets), Shayyaf (suppository), Sharbat (syrup), Araqiyat (distillates) etc. are being practiced for the curing of numerous disorders. Among them Sharbat is the formulation which is prescribed for treatment of different ailments such as Sual (cough) and Amraz-e-jild wa Fasad-e-Khoon (skin diseases and blood putrefaction) etc.

\section{SHARBAT}

Generally, the word Sharbat (English, sherbet) is derived from Persian "Sharbat", and sherbet is from Turkish "Serbet", both of which come from Arabic "Sharba" a drink, from "Shariba" to drink which is prepared from white sugar, honey, misri (rock sugar) and jaggery dissolved in water.It is an important invention of a renowned Unani physician, Pythagoras (an ancient Greek philosopher and mathematician). Characterization of Sharbat includes its sweet taste (i.e., good palatability) which is the prime reason to prepare this dosage form because of impalatable raw herbal drugs. It is prepared by the decoction or infusion of its ingredients or by preparing the juice of the fruit and then the decoction is mixed with sugar and boiled to a required consistency i.e. one tar. ${ }^{1-3}$ 


\section{SHARBAT-E-UNNAB}

Sharbat-e-Unnab is an important Unani sharbat mentioned in different Unani classical literature. This formulation is practiced as Dafa-e-Sual (antitussive) for curing of sual (cough) and Khashunat-e-Halaq (Sore Throat). This formulation has various actions such as Musaffi-e-Khoon (blood purifier), Musakkine-Hiddat-e-khoon etc, in Amraz-e-Jild wa Fasad-e-Khoon (skin diseases and blood putrefaction) like Judri (small pox) and Mashara (urticaria).4,5Unnab fruit is used in poor appetite and colitis. ${ }^{6}$ It is recommended for prophylaxis and for providing relief in upper respiratory tract infections in mild cases during COVID-19.7 Syrup of dried fruit is used for bronchitis. ${ }^{8}$ Unripe and acrid Unnab are useful in diarrhoea and various diseases of rectum. The drug is also recommended prophylactically for ailments of liver. ${ }^{9}$

\section{UNNAB (Ziziphus jujuba Mill.)}

The shrub of Unnab is spiny deciduous or a small tree having height up to 10-12 m. It is usually cultivated in India, Australia, China, Japan, Afghanistan, Africa and Malaysia. ${ }^{10}$

\section{Medicinal actions of Unnab ${ }^{5,7,11-15}$}

Musaffi Khoon (purifier of blood); Munzij-e-Akhlat-e-Ghalizah (concoctive of viscous humour); Mulaiyin e Sadr (lungs emollient); Munaffis Balgham (expectorant); Dafe Sual wa Rabu (antitussive and for asthma); Mulaiyin (laxative); Musakkin-e-Hiddat-e-Khoon wa Safra(blood and bile refrigerant); Muza"if-e-Bah (anaphrodisiac); Mundamil-eQuruh (cicatrizant); Dafe Alam (analgesic); Mukhaddir (anaesthetic); Dafe Hikka (anti pruritus); Habisuddam (styptic); Muqawwi-e-Meda (stomachic).

\section{Therapeutic uses of Unnab}

Busoor (skin eruptions);17Amraz-e-Riatain (lungs disorders); Mashara (urticaria); Amraz-e-Sadar (thoracic diseases); Lazae-Meda (stomach irritation);Judri (small pox);Hasba (measles); Khashunat-e-Halaq (sore Throat); Sozish-e-Baul (burning micturition); Surfa Yabis (dry cough); Damma (asthma);Bahhat us Saut (hoarseness of voice); Hikka (pruritus). 5, 11,18

\section{Phytochemical constituents}

Various significant chemical constituents are observed in Ziziphus jujube Mill.: Cyclic peptide alkaloids, Antibacterial peptide alkaloid; Glycosides, Acylated flavone-C glycosides; Saponins; Terpenoids, Triterpene esters; Phenolic and Flavonoid compounds . $^{19-21}$

\section{PHARMACOLGICAL ACTIONS OF UNNAB}

\section{Antioxidant activity}

A comparative study was conducted on antioxidant components and antioxidant activity of the raw and cooked peel of Ziziphus Jujuba Mill. In this study, the peel was analyzed for polyphenols, glutathione and tannin contents. Also, methanol and aqueous extracts were analyzed for flavonoid, saponin contents and antioxidant activity. It was observed that antioxidant activities of all the extracts increased with rising concentration except in hydro alcoholic extract. The results of the study showed the raw and cooked peel of Ziziphus jujuba Mill. have a great potential for utilization as a source of natural antioxidant. ${ }^{22}$

\section{Anticancerous activity}

A study was carried out to evaluate the anticancerous activity against tumour cell lines i.e., the cytotoxic triterpenoids which is extracted from the fruits of Zizyphus jujube. In this study, the lupane-type triterpenes showed high cytotoxic activities. The results of the study concluded that the coumaroyl moiety at the $\mathrm{C}-3$ position of the lupane-type triterpene which may play an important role in enhancing cytotoxic activity. 23

\section{SCIENTIFIC STUDIES ON SHARBAT-E-UNNAB}

A clinical study was conducted to assess the safety and efficacy of two Unani Pharmacopoeial formulations Itrifal Shahatra and Sharbat Unnab in the management of Acne vulgaris. Thirty-six patients diagnosed with acne, were included and diagnosed on the basis of history and dermatological examination. The test drugs were administered orally for 21 days. The results of the study showed significant reduction in the grading and VAS scores of post-treatment group $(\mathrm{P}<0.01)$ as compared to pre-treatment scores. It was observed that the test drug do not had any adverse effects and its compliance was also good. Therefore, it was concluded that the test drugs are safe and effective in the management of Busoor-e-labniyah (Acne vulgaris) .24

An open labeled randomized standard controlled study was carried out to evaluate the efficacy of Sharbat-e-Unnab in Primary Hypertension. This study was conducted up on forty cases randomly assigned to test $(\mathrm{n}=20)$ and control group $(n=20)$. Sharbat-e-Unnab $(25 \mathrm{ml}$ twice a day orally after meal $)$ was given to test group and Atenolol (1 tablet- $25 \mathrm{mg}$ per day orally after meal) to control group, for 6 weeks. The results of the study revealed that test drug is effective in reducing both subjective and objective parameters (B.P) without any adverse effect. Thus, it can be concluded that test drug was found effective in the management of Hypertension. ${ }^{25}$

\section{METHODS OF PREPARATION}

According to Unani classical literature, the preparation of Sharbat-e-Unnab contains only 1 ingredient i.e., Unnab (Zizyphus jujube Mill.). In Table No. 1, the formula for preparation of Sharbat-e-Unnab mentioned in Bayaz- eKabeer, Vol-II \& NFUM as following; 2,3

Table 1: the formula for preparation of Sharbat-e-Unnab

\begin{tabular}{|l|l|l|}
\hline S. No. & Ingredients & Weight \\
\hline 1. & Unnab (Zizyphus jujube Mill.) & $500 \mathrm{~g}$ \\
\hline 2. & Sugar & $1500 \mathrm{~g}$ \\
\hline
\end{tabular}

\section{Preparation of Sharbat-e-Unnab}

The method of preparation of Sharbat-e-Unnab is as per Bayaz -e - Kabeer Vol II and National Formulary of Unani Medicine(NFUM).Soak Unnab (500gm) after crushing in 1.5 liters of water. Thereafter, boil soaked Unnab till the quantity of water becomes half and these are thoroughly mashed and filtered. This form is called Joshanda (decoction) of Unnab. Thereafter, sugar is added in the decoction to achieve Qiwam (consistency) of Sharbat at full flame and if any impurity accumulates on the top level of Sharbat that should be removed by using spoon. Conventionally the consistency is made of ek tar (70\% in consistency). Afterwards, it is kept aside for cooling; and after filtration the Sharbat should be stored in bottles. ${ }^{2,3}$

Another method of preparation as per Qarabadeen-e-Majeedi is take the Unnab 600gm and crush them in small pieces and soak overnight in 4 liters of water. Then, boil soaked Unnab in morning till the quantity of water becomes half, after that they are filtered with the help of muslin cloth. Thereafter, the sugar is added and the mixture is heated, if any impurity accumulates on the top level of Sharbat that should be 
removed by using spoon. After achieving the consistency of Sharbat, filter and store in bottles. ${ }^{1}$

\section{Actions and Uses of Sharbat-e-Unnab}

Musaffi-e-khoon (blood purifier); 4 Musakkin-e-hiddat-e-khoon (blood and bile refrigerant); 1 Dafa-e-Suaal (antitussive); 4 Muskkin-e-alam-e-sadr (analgesic); 6 Munaffis-e-Balgham (expectorant);4, 26 Mashra (urticaria);28 Judri(small pox); Hasba (measles);28 Waja-ur-sadr (chest pain); ${ }^{29}$ Suaal (cough); ${ }^{30}$ Zat ur Riya(pneumonia). ${ }^{31}$

Dosage and Method of administration: 2- 4 Tola (24- 48 ml);4,29 4 Tola (48ml) with Arq Mundi 5 Tola $(60 \mathrm{ml})$ and Arq Gaozaban 7 Tola $(84 \mathrm{ml}) .{ }^{3120}$ to $50 \mathrm{ml}$ with water or with any Arq or goat milk. ${ }^{2,32}$

\section{DISCUSSION}

Sharbat-e-Unnab is widely used for Dafa e Sual (antitussive) for the treatment of sual (cough) and Khashunat-e-Halaq (Sore Throat). Unnab fruit is the main ingredient of the Sharbat and is recommended for prophylaxis and for providing relief in upper respiratory tract infections in mild cases during COVID19. Unnab is deciduous or small tree with a height of 10-12 m. It has various medicinal actions and uses such as Mulayyin-eSadr (emollient of lungs); Munaffis Balgham (expectorant); Dafe Sual wa Rabu (antitussive and anti-asthma), Surfa Yabis (dry cough); Damma (asthma); Bahhat us Saut (hoarseness of voice), etc. Unnab has several important chemical constituents like Cyclic peptide alkaloids, Cyclopeptide alkaloids, Antibacterial peptide alkaloid etc. Pharmacological studies are carried out on Unnab for Antioxidant activity and Anticancerous activity.

Sharbat e Unnab is a popular formulation mentioned in Unani classical literature and is being manufactured by various GMP certified pharmaceutical companies such as Hamdard laboratory and Rex Remedies Pvt. Ltd and New Shama Laboratories Private Limited. It has various actions as Musaffie-Khoon (blood purifier), Dafa-e-Suaal (antitussive), Munaffise-Balgham (Expectorant), Mashra (urticaria), Suaal (cough) and Zat ur Riya (pneumonia) etc. scientific studies on Sharbat Unnab have been done on Acne vulgaris and Primary Hypertension.

\section{CONCLUSION}

Sharbat is one of the Unani drug dosage forms. In Unani tibb, Sharbat is concentrated liquid which is prepared from decoction or fruit juices by adding sugar to yield a required consistency. Sharbat-e-Unnab is an important Unani compound formulation mentioned in different Unani classical literature whose main ingredient is Unnab. This formulation has various actions such as Dafa e Sual (antitussive), Musaffi-eKhoon (Blood purifier), Musakkine-Hiddat-e-Khoon (suppressive blood heat) etc. Unnab fruit is the main ingredient of this sharbat which is used for poor appetite, colitis, bronchitis, cough, etc. Some scientific studies on Sharbat e Unnab have been done on Acne vulgaris and Primary Hypertension. This formulation may be considered for further studies to explore its other pharmacological actions.

\section{Financial support and sponsorship: Nil.}

Conflicts of interest: There are no conflicts of interest.

\section{REFERENCES}

1. Anonymous. Qarabadeen-e-Majeedi. New Delhi; All India Unani Tibbi Conference: 1986, pp.197-198.

2. Kabeeruddin M. Bayaz kabeer Part 3. New Delhi: Idara Kitab us Shifa pp 71-77, 2010.
3. Anonymous. National formulary of Unani Medicine, Part -VI. Govt. of India, Ministry of Health \& Family Welfare, CCRUM; 2011: 116.

4. Ghani N. Khazainul Advia, Vol. III: Shaikh Md Basheer\& Sons, Urdu Bazar, Lahore; YNM. P. 142-144

5. Khan HS. Ilajul Amraz, New Delhi: CCRUM Dept of AYUSH Govt of India, 2005.

6. Agarwal V. Economic Plants of India, Calcutta: Kailash Parakashan, 1990; 413.

7. Anonymous. Guidelines for Unani Practitioners in COVID-19. Ministry of AYUSH, Govt. of India, 2020.

8. Chopra RN, Nayar SL, Chopra IC. Glossary of Indian Medicinal Plants, New Delhi: CSIR, 1956; 262.

9. Al-Bairuni AR. Saidana (Persian), Iraj Uftad Iran: Manuchahar Satuda, NYM, p. 932.

10. Prajapati ND, Pruhit SS. A Hand Book of Medicinal Plants, India: Agrobios, 2003; 553.

11. Khan HMA. Mohit-e-AZAM, vol. III, New Delhi: CCRUM Dept of AYUSH Ministry ofHealth \& Family Welfare Govt of India, 2014; 604-606.

12. Masihi ASA. Kitabul Miah, vol. I, New Delhi: CCRUM Dept of AYUSH, 2014; 219.

13. Haleem HMA. Mufradat-e-Azeezi, New Delhi: CCRUM Dept of AYUSH, 2009; 30.

14. Anonymous. NFUM Part 3, New Delhi: Dept of ISM\&H Ministry of Health \& FamilyWelfare Govt of India, 2001; 127-128,133.

15. Hussain SF. Advia Mein Kam Aane Wale Paude, Lahore: Urdu Science Board 299 UpperMal Lahore, 1990; 25.

16. Kabeeruddin HM. Makhzanul Mufradat, New Delhi: Aijaz Publishing House, YNM, pp.403-404.

17. Anonymous. The Wealth of India Vol XI x-z, New Delhi: Publication \& InformationDirectorate CSIR New Delhi, 1976; 111,112.

18. Ibn-e-Baitar, Al Jame li Mufradatil Advia Wal Aghziya, vol. 3, New Delhi: CCRUMDept of AYUSH Ministry of Health \& Family Welfare Govt of India, 1999; 314-316.

19. Lee S, Park JG, Lee YH, Lee CG, Min BS, Kim JH, "Anticomplementary activity of triterpenoides from fruits of Zizyphus jujuba," Biological and Pharmaceutical Bulletin,2004; 27(11):1883-1886. https://doi.org/10.1248/bpb.27.1883

20. Matsuda H, Murakami T, Ikebata A, Yamaharaj J, and Y yoshikawa M. "Bioactivesaponins and glycosides. XIV. Structure elucidation and immunological adjuvant activity of novel proto jujubogenin type triterpene bisdesmosides, protojujubosides A, B, and B1,from the seeds of Zizyphus jujuba var. spinosa (Zizyphi Spinosi Semen)," Chemical and pharmaceutical bulletin, 1999; 47(12):1744-1748. https://doi.org/10.1248/cpb.47.1744

21. Mahajan R, Chopda M. "Phyto-Pharmacology of Ziziphus jujuba Mill-A plant review.,"Pharmacognosy Reviews., 2009; 3(6):320.

22. Esteki T, Urooj A. "Antioxidant components and activity in the peel of Ziziphus JujubaMill.," Journal of Pharmacy Research, 2012; 5(5):2705-2709.

23. Lee SM, Min BS, Lee CG, Kim KS, Kho YH. "Cytotoxic triterpenoids from the fruits of Zizyphus jujuba," Planta medica, 2003; 69(11):1051-1054. https://doi.org/10.1055/s-2003-45155

24. Mahboobus S. et. al, A Preliminary Study On The Efficacy And Safety Of Two Unani Pharmacopoeial Formulations (Itrifal Shahatra And Sharbat Unnab) In Adolescent And Young Adults Cases Of Acne Vulgaris (Busoor-Ilabaniyah): Single Armed Open Labelled Clinical Study. World Journal Of Pharmaceutical And Medical Research. 2020; 6(4):85-89.

25. Shahid M. Evaluation of the Efficacy of Sharbat-e-Unnab in Primary Hypertension-An open labeled randomized standard controlled study. Bangalore. National Institute of Unani Medicine; 2018 [Cited 2021 may 26]. http://localhost:8080/xmlui/handle/123456789/37630 .

26. Amrohvi J. Qarabadeen-e-Jalali, New Delhi: CCRUM Dept of AYUSH Ministry of Health \& Family Welfare Govt of India, 2006.

27. Khan HMA. Qarabadeen-e-Azam, New Delhi: Aijaz Publishing House Daryaganj, 1996.

28. Chughtai HGM. Bayaz-e-Firozi, Lahore: Shaikh Basheer \& Sons Chowk Urdu BazarLahore, 1995.

29. Lubhaya R. Dehlike Muntakhab Murakkabat, New Delhi: Goswami Kutub Khana Gali Qasim Jan Delhi, 1979.

30. Jeelani G. Kitabul Murakkabat (Makhzanul Murakkabat), New Delhi: Eajaz Publishing House, 1995.

31. Jurjani AAH. Zakheera Khawarzum Shahi, vol. 10, Lucknow: Matba Nami Munshi Nawal Kishor, 1903.

32. Arzani MA. Meezanut Tibb, Deoband: Faisal Publisher, YNM 